\title{
Islamic Republic of Afghanistan: Poverty Reduction Strategy Paper- Progress Report
}

Poverty Reduction Strategy Papers (PRSPs) are prepared by member countries in broad consultation with stakeholders and development partners, including the staffs of the World Bank and the IMF. Updated every three years with annual progress reports, they describe the country's macroeconomic, structural, and social policies in support of growth and poverty reduction, as well as associated external financing needs and major sources of financing. This country document for Islamic Republic of Afghanistan, dated January, 29, 2008, is being made available on the IMF website by agreement with the member country as a service to users of the IMF website.

To assist the IMF in evaluating the publication policy, reader comments are invited and may be sent by e-mail to publicationpolicy@imf.org.

Copies of this report are available to the public from

International Monetary Fund • Publication Services

$70019^{\text {th }}$ Street, N.W. $\bullet$ Washington, D.C. 20431

Telephone: (202) 623-7430 • Telefax: (202) 623-7201

E-mail: publications@imf.org • Internet: http://www.imf.org

Price: $\$ 18.00$ a copy

\section{International Monetary Fund Washington, D.C.}





\section{Islamic Republic of Afghanistan Afghanistan National Development Strategy (ANDS)}

\section{PROGRESS REPORT OF ANDS/PRSP PREPARED FOR IMF/WORLD BANK BOARD OF DIRECTORS}

(2006/2007) 


\section{Acronyms}

\begin{tabular}{|c|c|}
\hline ANDS & Afghanistan National Development Strategy \\
\hline ADF & Afghanistan Development Forum \\
\hline ACBAR & Agency Coordinating Body for Afghan Relief \\
\hline CMRS & Centralized Monitoring and Reporting System \\
\hline CSO & Central Statistics Office \\
\hline DIAG & Disarmament of Illegally Armed Groups \\
\hline EAG & External Advisory Group \\
\hline FCCS & Foundation for Culture and Civil Society \\
\hline HIPC & Heavily Indebted Poor Countries \\
\hline $\mathrm{JCMB}$ & Joint Coordination and Monitoring Board \\
\hline IMF & International Monetary Fund \\
\hline MoF & Ministry of Finance \\
\hline MM & Monitoring Matrix \\
\hline MRRD & Ministry of Rural Rehabilitations and Development \\
\hline Mol & Ministry of Interior \\
\hline MoD & Ministry of Defense \\
\hline NGOs & Non Governmental Organizations \\
\hline OSC & Oversight Committee (ANDS) \\
\hline PDCs & Provincial Development Councils \\
\hline PDPs & Provincial Development Plans \\
\hline PIP & Public Investment Programs \\
\hline SSDGs & Sector Strategy Development Groups \\
\hline UNDP & United Nation Development Program \\
\hline
\end{tabular}




\section{Table of Contents}

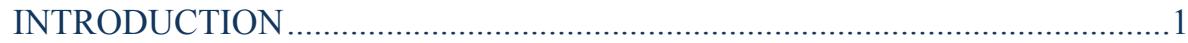

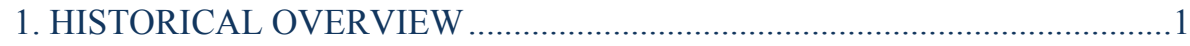

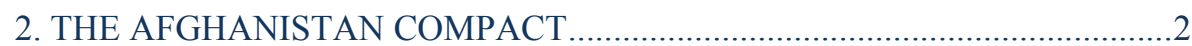

3. VISION 2020: MILLENNIUM DEVELOPMENT GOALS .............................3

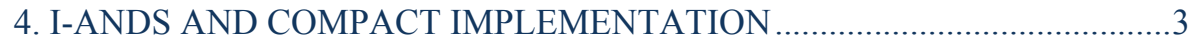

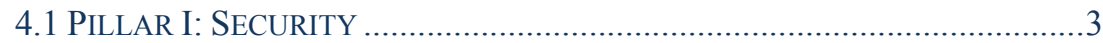

4.2 PILlAR II: GOVERNANCE, RULE OF LAW AND HUMAN RIGHTS ..............5

4.3 PILLAR III: ECONOMIC AND SOCIAL DEVELOPMENT .................................

5. MAJOR PROGRESS IN REBUILDING INFRASTRUCTURE AND ..........10

6. THE JOINT COORDINATION AND MONITORING BOARD (JCMB) .....11

7. DEVELOPMENT OF THE FULL ANDS (PRSP) ........................................12

7.1 AN “AfGHANIZED” Plan For AfGHANISTAN .......................................12

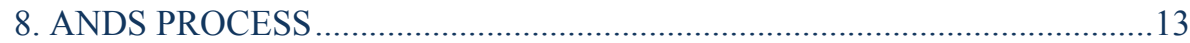

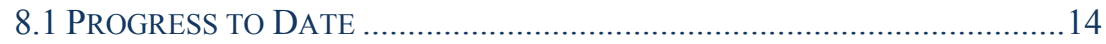

8.2 PREPARATION OF THE MINISTRY/AGENCY STRATEGIES ........................15

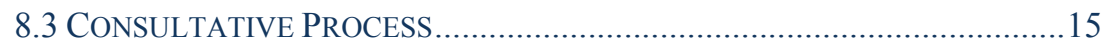

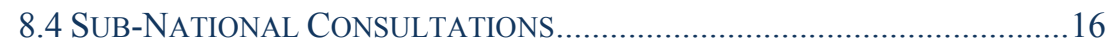

8.5 NATIONAL CONSULTATIVE PROCESS: ................................................... 18

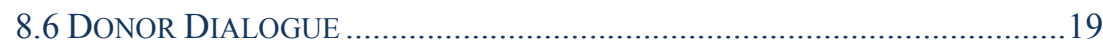

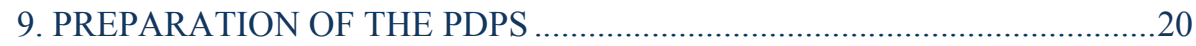

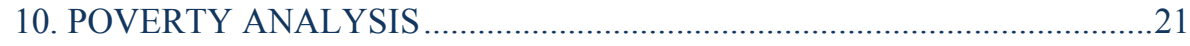

11.FINALIZATION OF THE ANDS SECTOR STRATEGIES ….....................22

12. PRIORITIZATION AND BUDGET INTEGRATION …...............................22

12.1 AID COORDINATION AND AID EFFECTIVENESS ..................................23

12.2 IMPLEMENTATION, MONITORING AND EVALUATION ………………....23

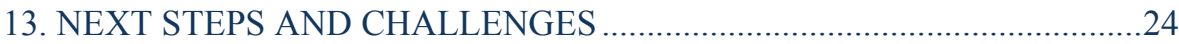

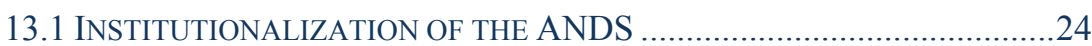

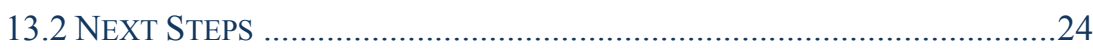

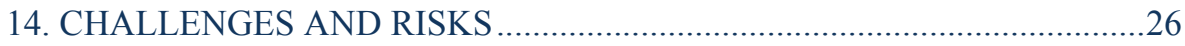




\section{Introduction}

At a High-Level Joint Coordination and Monitoring Board (JCMB) meeting at the United Nations General Assembly in New York earlier this year, H.E. President Hamid Karzai stated that, "the Afghanistan National Development Strategy is the blueprint for Afghanistan's development". The Afghan Government, supported by the international community, aims to deliver on its development goals and priorities in a nationwide effort to improve the lives of its people. The present challenge for the Government is to finalize the ANDS, based on the I-ANDS, consultations and research, and move towards its Afghanistan Compact obligations. Throughout the development of the ANDS, the Government has taken care to ensure ownership over the process, thereby consolidating a truly "Afghanized" development vision and strategy for the country, with fully synthesized, costed, prioritized and sequenced projects and programmes for poverty reduction and economic growth.

\section{Historical Overview}

Afghanistan's recent history has significantly influenced its current state of development. The legacy of communist rule has left the country economically undeveloped and politically divided. Though the Afghan resistance to Soviet occupation led to national liberation, the country remained torn by years of subsequent conflicts and injustice. This situation was exacerbated by global events and internal strife followed by Taliban rule, which left Afghanistan as one of the poorest countries in the world. The successive wars killed over a million Afghans, forced about third of the population into exile, left around 800,000 people permanently disabled and many families without breadwinners.

In December 2001, after the fall of the Taliban and after twenty-three years of uninterrupted war, the Transitional Administration of Afghanistan assumed authority over the country in line with the conclusions of the Bonn Conference that led to the approval of interim arrangements pending the re-establishment of a functioning Government.

At that time, with a GDP of approximately US\$200 per capita, the Afghan economy was virtually destroyed. Agriculture land and pastures were heavily contaminated with land mines and unexploded ordinance making the country's large rural population even more vulnerable to extreme poverty. The infrastructure for managing scarce water supplies was devastated. The few remaining roads and bridges were barely useable due to the long absence of basic maintenance. Many schools and hospitals were destroyed. Several generations had no access to an education. The public finance and the tax system were non-existent and the country became even more heavily dependent on donor assistance.

The immediate concern of the Transitional Administration was to address the humanitarian needs of the people, ensure voluntary refugee return, build basic state institutions, reform the political system and prepare for democratic elections. Despite devastating droughts and the unexpected large return of refugees, the Transitional Administration together with its international partners managed to prevent major humanitar- 
ian crises. The political transition led to the emergence of cultural pluralism, involvement of women in public life, free media, and the freedom of expression and assembly. The elections for National Assembly in September 2005 led to the establishment of the democratically elected Government of Afghanistan and the development of the Interim Afghanistan National Development Strategy (I-ANDS)

One of the main goals of the newly elected Government was to develop and implement a national development strategy that would act as a guide to Afghanistan's economic revival. The Interim Afghanistan National Development Strategy (I-ANDS) which was presented to the international community at the London Conference in February 2006, filled this role. Through the I-ANDS, President Hamid Karzai laid out the Government's plans for achieving accelerated progress in security, governance, the rule of law, and economic development. The London Conference supported the implementation of the I-ANDS (through the Afghanistan Compact) by pledging a US\$ multi-billion reconstruction program.

The I-ANDS was based on the Millennium Development Goals (MDGs) and contained three pillars: (a) Security; (b) Governance, Rule of law and Human Rights; and (c) Economic and Social Development. The policies were laid

"Afghans today stand with the dignity and declare to the world that we are rising from the ashes of invasion and will live forever".

President Hamid Karzai, December 2005 down through eight sectors and six cross-cutting issues.

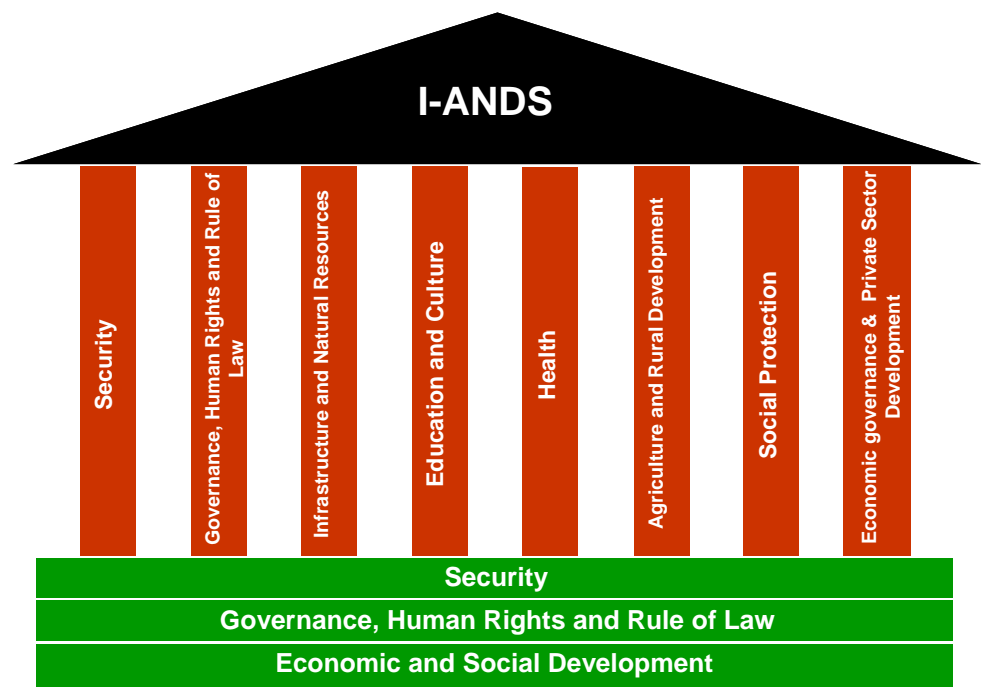

\section{The Afghanistan Compact}

The London Conference welcomed the preparation of the I-ANDS and endorsed the benchmarks contained in the Afghanistan Compact (Compact) and its five-year timeline for implementation. The Compact was approved in the spirit of the UN Security Council Resolution 1659 (2006), which expressed a common commitment for the Government of Afghanistan and the International Community to build a state that will provide security and licit livelihood opportunities for all Afghans. 
The progress in implementation of the Compact is measured through 42 benchmarks, which are grouped in three overarching pillars. The Joint Coordination and Monitoring Board (JCMB), containing representatives of the International Community, were tasked to coordinate and monitor the implementation of the Compact benchmarks through Consultative Groups (CG) and Working Groups (WG). The JCMB has

"Our vision for the Islamic Republic of Afghanistan is to consolidate peace and stability through just, democratic processes and institutions, and to reduce poverty and achieve prosperity through broad based and equitable economic growth."

I-ANDS

been reporting on a regular basis, progress in implementation of the Compact benchmarks to the President, the National Assembly, and the UN Secretary General as well as to donors and the public.

\section{Vision 2020: Millennium Development Goals}

Prior to approval of the I-ANDS and the Compact, the Government of Afghanistan had approved its strategy for achieving the MDGs (2005). Apart from poverty, ill health and poor education, the strategy addressed the issue of security as one of the greatest problems for the Afghan people. The lack of security has proven to be a substantial obsta-

\section{Vision 2020}

Afghanistan "Vision 2020" collectively reflects Afghanistan's aspirations for its people of reducing poverty and hunger, providing universal primary education, reducing child mortality, improving maternal health, combating diseases, promoting gender equality, ensuring environmental sustainability and enhancing personal security.

Source: MDGs, Islamic Republic of Afghanistan, Country Report 2005

cle for private sector development and economic growth, education and more effective public service delivery. Thus, security was added as an additional MDG for Afghanistan.

\section{I-ANDS and Compact Implementation}

\subsection{Pillar I: Security}

Both the Government of Afghanistan and the international community confronted security challenges in the past year in the south and southeast of Afghanistan. The deeply regretful civilian and military casualties of these battles prevented the opponents of this process from derailing it, as they had hoped, and enabled Afghanistan to continue to move forward.

In the defense sector, the international community increased its military support for Afghanistan during this period, completing the final stage of expansion of the International Security Assistance Force (ISAF) under NATO command. International troop presence now stands at the highest level since 2001, with a combined total of over 
43,000 troops $(35,000$ NATO and 8,000 Coalition). Beyond its combat role, ISAF has taken over from the Coalition and established Provincial Reconstruction Teams (PRTs) in twenty-five of Afghanistan's thirty-four provinces. It will be important to ensure that international forces and the PRTs adopt a uniform approach to ANDS and are structured to support the Government and civilian development actors. ${ }^{1}$

The Afghanistan National Army (ANA) achieved strength of 42,200 and successfully executed both independent and complex joint operations with ISAF on a daily basis. In order to maintain the hard-won initiative, the ANA will need to take on further leadership of security operations and improve the retention of trained soldiers. It is making further requests from its international partners for sufficient quantities of modern equipment. Donor attention is needed to identify and deliver immediate requirements that will enhance their operational capabilities.

In the future, efforts must be made to transform the MoD into a sustainable institution alongside the ongoing efforts to maintain ethnic balance and increase the ANA's operational capabilities. A long-term model that balances both Afghanistan's defense requirements and the country's financial capacity is urgently needed before the ANA expands beyond levels sustainable by the government and people of Afghanistan.

The resources available for strengthening and equipping the Afghan Border Police (ABP) are tied to the Afghanistan National Police (ANP) as a whole. A lack of border posts and an absence of modern surveillance technology are key gaps in efforts to confront both armed groups with sanctuary in neighboring countries and international drug traffickers. ${ }^{2}$

In the internal security and law enforcement sector the ANP has rapidly expanded, establishing a visible presence across the country. The ANP is close to completing pay and rank reform of senior ranks, and has also established as a temporary measure the Afghan National Auxiliary Police (ANAP), starting in six provinces of the South and South-East. Greater international coordination is needed to help the Government manage institution building efforts in the MoI, and enhanced assistance for the MoI is needed to create a comprehensive road map outlining the requirements for managing and coordinating a wide range of activities, to include civil administration. ${ }^{3}$

The National Drug Control Strategy (NDCS) moved towards full implementation, with regional cooperation initiatives relating to drugs still in their nascent stages and eradication efforts destroying more than 32,000 hectares of poppy, however eradication has at times reflected a patchy approach, and this year's opium poppy production is expected to exceed last year's record harvest. While the bulk of opium poppy cultivation is concentrated in the south in insecure areas, in the north, adequate licit live-

\footnotetext{
${ }^{1}$ JCMB Annual Report, 2007

${ }^{2}$ JCMB, Annual Report, 2007

${ }^{3}$ JCMB, Annual Report, 2007
} 
lihood projects have led to a notable decrease in poppy cultivation. Establishing and equipping a specialized Counter Narcotics Police (CNP) section in the MoI began. ${ }^{4}$

The Action Plan for Disbandment of the Illegal Armed Groups (DIAG) have been approved: 183 illegally armed groups have pledged to disband their groups and disarm. A total amount of 30000 light weapons have been collected as well as over 4000 heavy weapons. Ten districts have been declared DIAG complaint. Efforts are being made to work with the District Development Assemblies (DDAs) in identification and implementation of the development projects to support DIAG process. ${ }^{5}$

Remarkable success was achieved in the demining sector through the Mine Action Program for Afghanistan (MAPA), having cleared 132 million square meters of land, and destroying stockpiles of more than 14,000 anti-personnel landmines during the past year. However, a chronic lack of funding for de-mining activities and the challenge of the last remaining stockpile of anti-personnel landmines in Afghanistan are key issues preventing greater success. ${ }^{6}$

\subsection{Pillar II: Governance, Rule of Law and Human Rights}

Since approval of the I-ANDS the Government has been streamlined: the number of Ministries was reduced to 25 Ministries to reflect core functions and more efficient models of service delivery while eliminating some functional duplication. Civil service capacity has increased since 2002 through the Priority Reform and Restructuring (PRR) programme and other schemes under the Government's capacity building framework.

Seventeen Ministries have completed Stage 2 of Priority Reform and Restructuring (PRR) program. Significant progress has been made in the development of a framework for Public Administrative Reform (PAR), to allow for the shift from an ad hoc approach in support of a common strategy and a costed implementation plan for the Civil Service Reform Component. Afghan Independent Administrative Reform and Civil Service Commission (IARCSC) oversight capacity has been increased.

The Afghan Independent Administrative Reform and Civil Service Commission (AIRCSC) has undertaken a comprehensive review of the procedures and outputs of merit-based appointments and is in the process of implementing the recommendations arising from this review, including strengthening the existing mechanism to allow improved monitoring of appointments. The government has committed itself to dealing with staff surplus and a severance, and implementation plans are being developed.

An overall assessment and analysis on factors and situations leading to corruption has been conducted by the High Level Commission against Corruption. In addition to

\footnotetext{
${ }^{4}$ JCMB Annual Report, 2007

${ }^{5}$ JCMB VI Status Update, Annex One, 3 October 2007

${ }^{6}$ JCMB Annual Report, 2007
} 
causes of corruption, this assessment provided short term and long term recommendations aimed at preventing and fighting corrupted acts. Based on this a roadmap for "Fighting Corruption in Afghanistan - Strategy and Action" has been drafted.

In March 2007, the Supreme Court (SC), AGO and the MoJ presented their comprehensive new reform strategies. These strategies include plans restructure the institutions, develop merit-based and transparent recruitment, promotion and accountability mechanisms for improving professional standards, ethics and discipline, whilst also improving the conditions of service of justice officials and increasing women's representation at all levels of the justice system.

The International Community has begun monitoring the effectiveness and independence of the Afghan judiciary to identify issues, which impact on or impede the actual and perceived status, quality and independence of the judiciary. Currently, monitoring takes place in four provinces plus Kabul..

The Attorney General's Office (AGO) has drafted a code of ethics, which contains Disciplinary Procedures for Prosecutors. AGO will strengthen its capacity to investigate and take action on cases brought through internal oversight mechanisms as well as external agencies such as the Afghanistan Independent Human Rights Commission (AIHRC). The Ministry of Justice established a committee to review all laws and regulations and identify areas of improvement, including a code of ethics and professional standards. To combat corruption, the Ministry of Justice (MoJ) has made plans to strengthen its Inspection Department to bring it in line with international standards.

The construction of a new judicial complex in Jalalabad and other Justice Centers in Paktia, Balkh, Kunduz and Laghman Provinces have begun: 30 courthouses, 10 mixed-use facilities and 7 justice sector buildings have been renovated. The courts infrastructure will be improved in 1386 thanks to support from USAID.

To date 8 civil laws have been reviewed, amended and approved in 1385 (March 2006 - March 2007) as well as 17 commercial and 3 criminal laws. The Afghanistan Council of Ministers approved the 1386 legislative agenda (containing 32 laws) in October 2006 for the first time since 1993. As a part of justice reform the new laws have been drafted and submitted to Cabinet such as the Advocates Law (to support the establishment of an independent Afghan bar association to lead and regulate the profession), and legislation to reorganize the Legal Aid Department from the Supreme Court to the Ministry of Justice (MoJ).

A number of important laws will soon be approved. ${ }^{7}$

\footnotetext{
${ }^{7}$ Narcotics Law; the New Criminal Procedure Code; the new Law of the Attorney General's Office (AGO); Laws on Forestry, Private Education Facilities, Mortgages, Secured Transactions, Negotiable Instruments, Extradition, Leasing, Anti-terrorism law, Law on the Elimination of Violence against Women; Income Tax, law, law on the Prevention of the Extension and Production of Chemical Weapons, Contracts and Water Rights/Usage law, law on Personal Status of Shiites, Procurements regulations, Election law, Local Administration "Municipalities" law, Education law, Copy Rights law, Trade Marks law, Amendments to the Petroleum and Gas "Hydrocarbon" law
} 
The National Action Plan for Women of Afghanistan (NAPWA) was approved and its implementation has started with the aim of establishing gender equality (i.e. eliminating discrimination, building of women's human capital and promoting their participation and leadership).

\subsection{Pillar III: Economic and Social Development}

Overall macroeconomic performance has been in line with the I-ANDS objectives and the Compact benchmarks. Over the past four years, Afghanistan has experienced strong economic growth. Real growth rates have ranged from 26 percent in 2002/03 to 14 percent in 2005/06. The drought-induced decline in agricultural production held the real economic growth to an estimated 7 percent in 2006/07. Despite this, the average growth rates of 16 percent of GDP for the period of 2002/2006, put Afghanistan's growth rates well above of the average real growth rates of other post-conflict, landlocked countries. GDP per capita has increased by around 53 percent in the last five years and grew from around US\$200 to around US\$306. ${ }^{8}$ However, given the size of the informal economy the official GDP figures appear to be vastly underestimated. Preliminary assessments ${ }^{9}$ of the World Bank indicate that the grey economy, including sizeable opium production, could account for up to 80 percent of the official GDP.

and its regulation, Law of Personal Affairs of Civil Servants, Law of the Organization and Authority of Judiciary, Amendment of Anti Bribery and Corruption law, law of Regenerated ["Improved"] Seeds, Standardization law, Contracts law , Law of Kidnapping and Trafficking of Human Beings, law of Personal Affairs of the Police, Law of the Rights and Privileges of the Academic Cadre Members of Taqnin, Charter of General Department of Legislative Affairs and Academic Legal Research, Law of Governmental Cases, Regulation on Reduction and Reemployment, Law of Citizenship, Regulation of the Juvenile Rehabilitation Center, Civil Aviation law, Regulation of Prisons and Detention Centers, and Forensic law.

\footnotetext{
${ }^{8}$ Afghanistan Central Statistics Office

${ }^{9}$ State Building, Sustaining Growth, Reducing Poverty, World Bank, Country Report, 2004
} 


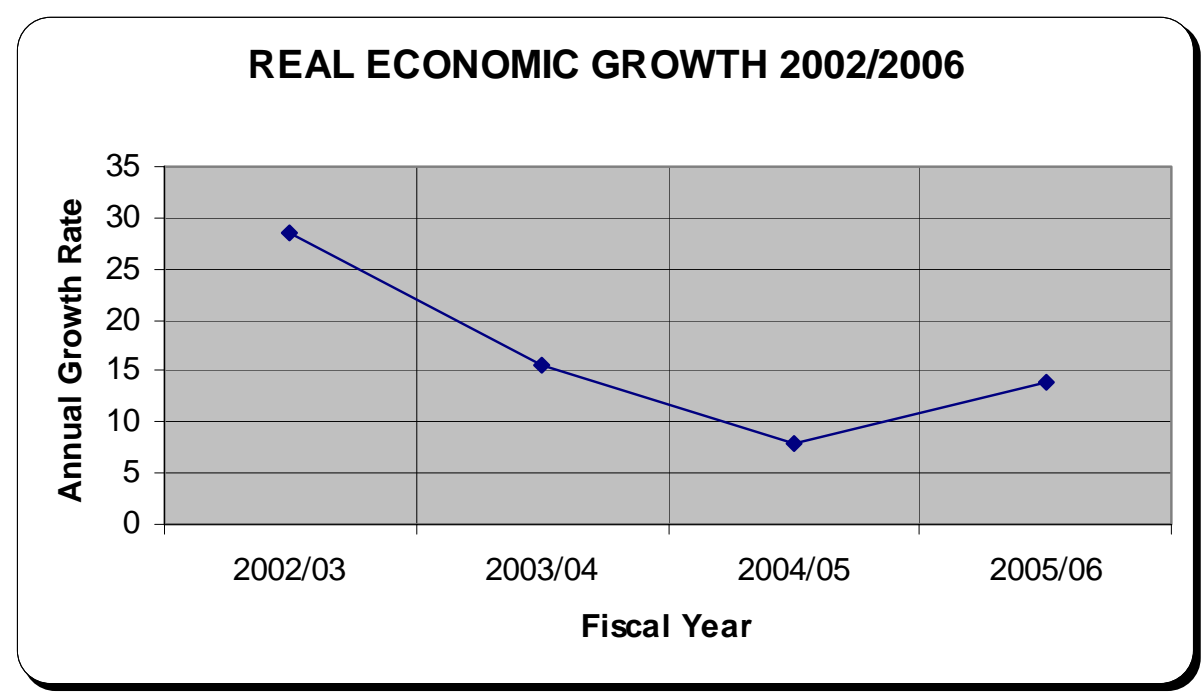

Source: Da Afghanistan Bank (Central Bank of Afghanistan)

Over the last five years, inflation has decreased to single-digit level. In 2003/04 the inflation rate reached 24 percent while in 2006/07 it was brought down to around 4.8 percent. To achieve its objective of keeping inflation low (single digits) the DAB relied on targeting currency-in-circulation. Monetary policy has been supported by the adherence to strong fiscal discipline and a "no overdraft" rule that prohibits the Central Bank from financing the deficit.

International reserves have increased further and the exchange rate has remained stable. Although bank operations continue to be heavily dollarized, the monetary developments point to increased confidence in the domestic currency (Afghani).

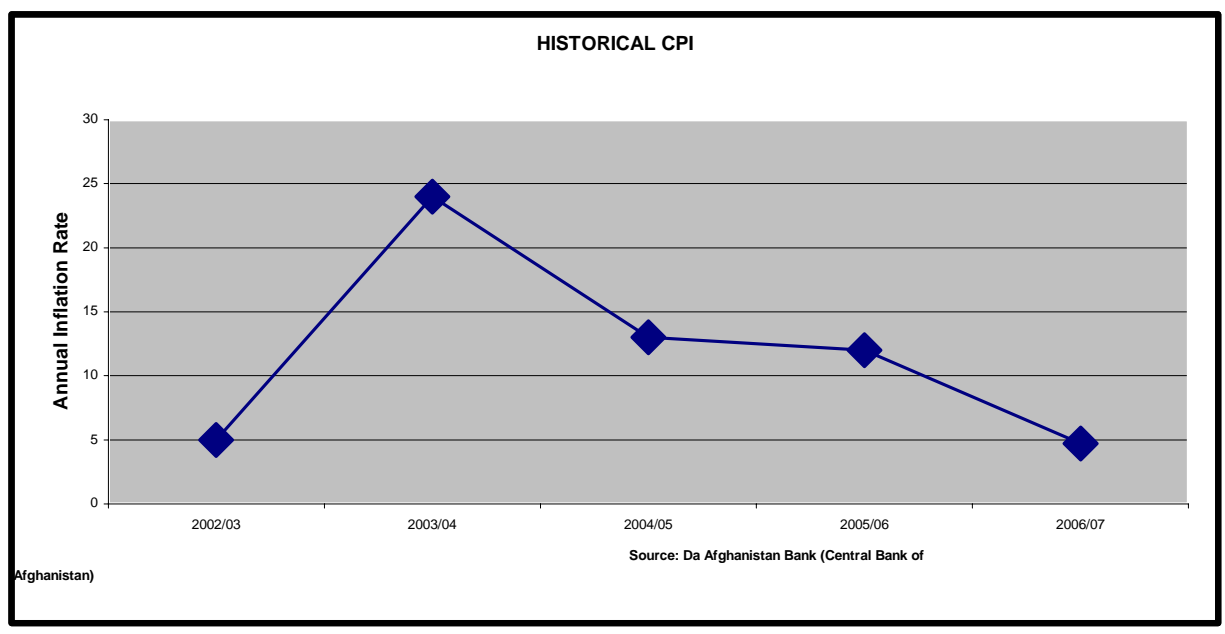

Afghanistan has experienced a steady growth in its domestic revenues. By 2006/07 domestic revenues grew almost 500 percent in relation to 2002/03 rates, reflecting acceleration in economic growth and stronger capacity for revenue collection. Fiscal reform led to the introduction of business taxes, rationalization of tariffs and strengthening of tax collection. Several important tax reforms are well advanced. Among them are the: (a) abolition of nuisance taxes; (b) reform of business receipt tax (BRT) (to move towards a broad-based consumption tax); (c) simplification of income tax 
and the introduction of a fixed tax regime for small businesses; and, (d) the introduction of tax refund processes.

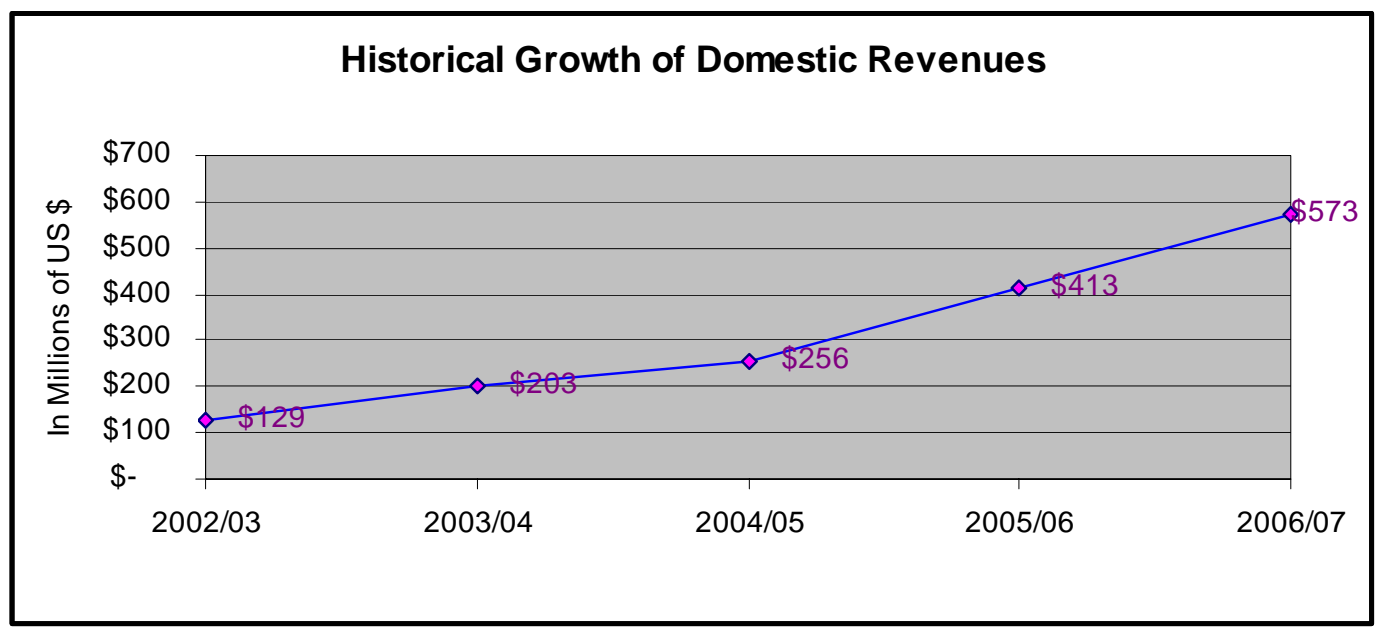

Source: $\mathrm{MoF}$

Fiscal performance in 2006/2007 was better than expected. In 2006/07 the Operating Budget deficit (excluding grants) was 3.6 percent of GDP compared to the projected rate of 4.1 percent. The execution of the Development Budget improved significantly and in 2006/07 was around 50 percent higher than in 2005/06. The overall Core Budget (Operation Budget plus Development Budget) deficit (including grants) narrowed to 2.7 percent of GDP compared to the projected rate of 3.8 percent.

Despite the progress in improving macroeconomic stability, poverty remains the

\section{People's perception of poverty in Afghanistan}

The most common answers when speaking about poverty are related to a situation of material deprivation (food, land, livestock). Most of the time, interviewees referred to a lack of food: "The poor are the ones with empty stomach" or those with an absence of surplus. "The poor are the ones who do not have enough milk to make yogurt". Many people also refer to an absence or lack of land or a lack of job opportunities, which leads to extreme vulnerability. The lack of capacity to plan the future was often associated with the definition of poverty. "The poor are the ones who can not foresee what will happen tomorrow". One man in Bamiyan province defined poverty saying: "the poor are the ones who can be sick today and be dead the next day".

Source: Final Draft Study on Chronically Poor Women, MoWA, 2007 number of "working poor" in Afghanistan. The low salaries, even of government employees, place many of the employed under the risk of falling below the poverty line. The analyses also showed that poverty was unevenly spread throughout Afghanistan: the poverty headcount rates of provinces vary from around 10 percent to more than 70 percent. Poverty is more severe in the Northeast, central highland and parts of the Southeast. Despite a significant increase in public spending in key sectors to support 
poverty reduction, the scarce domestic resources and limited international assistance managed to provide limited assistance only to poorest of the poor.

\section{Major Progress in Rebuilding Infrastructure and Human Capital}

Transport: 1,983 km of the Ring Road Network (RRN) has been reconstructed, or 59 percent of it. The Government Maintenance Plan was approved and an independent Road Fund aimed at improving the long-term fiscal sustainability will be created soon.

Energy: the rehabilitation of the North-East Power System (NEPS) has advanced. Electricity distribution rehabilitation and infrastructure projects in all major urban centers are underway. Access of the rural households to electricity has been increased by $7 \%$. Fiscal sustainability has been improved: currently $66 \%$ of the costs from the national power grid are recovered. A Renewable Energy Master Plan has been approved.

Natural Resources: Minerals Law and Hydrocarbon Law have been put in place and the Gas Law is in the final stage of approval. A Cadastre and Inspectorate will be established soon.

Education: The Ministry of Education (MoE) has completed the development of a 5year National Education Strategic Plan (NESP). Around 1000 schools have been or are under construction across the country. Gross enrolment in schools is estimated to have increased by $12 \%$ in 1385 to 5.4 million students of whom $35 \%$ are girls. Out of 50,000 students who graduated from Grade 12 in 1385, around 35,000 of them registered for the university entrance examination. Close to 17 million primary grade textbooks were printed and distributed; 56 titles of primary grade textbooks have been finalized and ready for printing. Twenty-three active teacher training colleges across the country have enrolled around 9,500 students. In 1385 nearly 285,000 students of which 180,000 were female, enrolled in literacy courses and 70,500 have graduated.

Health: Population coverage of the Basic Package of Health Services (BPHS) has increased from 77 to 82 percent. Immunization of children has been significantly improved. There has been a marked increase in health infrastructure; the number of health facilities providing the BPHS has increased to 897 (from 746), the number of health facilities providing Comprehensive Emergency Obstetric Care has also increased to 89 (from 79), and the number of health facilities within the Integrated Management of Childhood Illnesses reached the figure of 309 (located in eight provinces and 39 districts). Thirteen therapeutic feeding units have been established (from 13), and two additional midwifery schools were opened. Twelve mobile health facilities were established to provide basic health services to the Kuchi population. The number of health facilities providing direct observed treatment short courses (in the treatment of TB) increased to 55 percent (from 45 percent). Approximately 40000 insecticide bed nets were distributed to control the spread of malaria. Provincial teams in eight provinces were established to track the prevalence of avian flu. In total, 233 health facilities have been renovated or constructed. 
Developing the health sector's human capital has progressed: the number of active community health workers has increased to 15001 (from 12 000). Out of this total, 49.3 percent are women. Community midwife graduates numbered 388 in the reporting period. Health education and awareness efforts have continued. In total, 1084322 items and materials from the Information, Education and Communication program, have been distributed.

\section{The Joint Coordination and Monitoring Board (JCMB)}

Since the endorsement of the Compact, the JCMB has been meeting every three months_to review the progress in the implementation of the benchmarks and to provide guidance for further action. In the months since the first annual JCMB meeting, the Government-led Working Groups and more technically oriented teams, with support from the ANDS/JCMB Secretariat, have been instrumental in assessing progress, identifying bottlenecks and proposing corrective measures for implementation of the benchmarks. The Working Groups have provided crucial inputs to almost fifty ministerial and agency strategies. High-level participation from the Government side has meant that discussions and decision making among line ministries, inter-ministerial groups, and international partners have become more delivery oriented. Moreover, both the Government and international partners have looked for ways to make the JCMB mechanism even more effective, especially in areas such as counter-narcotics, policing, governance, anti-corruption, and counter-insurgency.

\section{Role of the JCMB}

The Joint Co-ordination and Monitoring Board (JCMB) is the primary co-ordinating and monitoring mechanism established between the Afghan Government and the international community for ensuring achievement of the Afghanistan Compact and the high level benchmarks. This role is being expanded to take care of monitoring for the full ANDS. The Board is a high level decision making body focusing on resolving strategic problems arising from the implementation of the Afghanistan Compact with three specific objectives:

(i) Provide high-level oversight of progress in the implementation of the political commitments of the Afghanistan Compact

(ii) Provide direction to address significant issues of coordination, implementation, financing for the benchmarks and timelines in the Compact, and any other obstacles and bottlenecks identified either by the government or the international community

(iii) Report on the implementation of the Compact to the President, National Assembly, the UN Secretary General, the donors, and the public

The Afghanistan Compact mechanism CGs/WGs has contributed to the monitoring and implementation of the benchmarks and as well as the enabling environment. A comprehensive monitoring mechanism is currently being developed in order to monitor progress under the Afghanistan Compact. The mechanism will be able to capture progress of process and progress indicators and status of projects, enabling follow- up by the JCMB. It is thus expected to play a critical role in the implementation of the ANDS. 
A high-level meeting, attended by H.E. President Karzai and the UN Secretary General, was held in New York on 23 September 2007 in the JCMB format to reaffirm a continued commitment to Afghanistan. The Rome Conference held on 2-3 July 2007 re-energized the development of the justice sector, and gave clear direction for the completion of the justice sector strategy within the process of preparation of the full ANDS. The Conference on 'Disbandment of Illegal Armed Groups (DIAG) for the Stabilization of Afghanistan' was held in Tokyo on 21 June 2007. It focused on an effective enforcement plan, and options for strengthening DIAG.

The Afghanistan Government supports the strengthening of the JCMB. The Government would like to see the JCMB more involved in tackling major issues. The transformation of the JCMB should evolve from its current function of coordination and monitoring to more of a problem solving body.

\section{Development of the Full ANDS (PRSP)}

\subsection{An "Afghanized" Plan for Afghanistan}

By mid-2006 the Afghan Government had embarked on the process of preparing the full ANDS. From the very beginning, the Government stated its goal to develop the ANDS in a highly participatory manner by involving all segments of the Afghan community. Moreover, the Government launched a number of research activities to ensure that the ANDS policies were to be evidence-based. However, the process required massive mobilization of the entire Government at the national and the subnational level. Despite this the Government's intention was to seize this historic opportunity and formulate an Afghan-owned development vision instead of implementing strategies that were mainly prepared outside of Afghanistan. Moreover, the Government's objective was to move from being a donor facilitator with regards to implementing projects to establishing itself as the main decision maker in determining the development priorities of the country.

The main general objectives of the ANDS are to improve the quality of life of Afghan people and to reduce poverty. Thus, for the Government of Afghanistan, the ANDS is also the Poverty Reduction Strategy (PRSP), which will be submitted to the Board of Directors of the World Bank and the IMF by the end of March 2008. The Government of Afghanistan expects that donors will align their spending with the ANDS priorities. Thus, the ANDS will play a key role in improving aid coordination and aid effectiveness.

Managing the expectations has always been an important concern. Early preparation of the macroeconomic framework, high-level discussions about prioritization and the ANDS media awareness campaign were the main instruments for establishing the framework for developing a realistic ANDS, within a prioritized fiscal envelope. 


\section{ANDS Process}

The ANDS process includes active interaction within and outside of the Government at the national and the sub-national level. In line with the President's decree, the ANDS Secretariat took a lead role in coordinating the preparation of the ANDS. In order to perform its task successfully, the ANDS was institutionalized within the Government and the sub-national administrations: each ministry has established ANDS focal points and rendered deputy ministers responsible for the ANDS process. Moreover, Governors Offices in all 34 provinces have established either an ANDS office or focal points.

The ANDS Oversight Committee (OSC), whose membership includes prominent ministers, has been meeting on regular basis to oversee the ANDS formulation process. It has also provided a platform for prioritization and consensus building. From the very beginning, the active involvement and ownership of the line ministries have been one of the greatest achievements of the ANDS.

\section{The ANDS Oversight Committee}

The Oversight Committee was formed by the Afghan Government to oversee the overall economic, policy and strategic direction for the implementation, monitoring and development of the ANDS and ensure that its objectives meet the Afghanistan Millennium Development Goals (MDGs). The Oversight Committee is composed of Cabinet Ministers, including the Ministers of Finance, Foreign Affairs, Economy and Labour, Justice, Education, Commerce and Industry and the Chair of the National Security Council. It is chaired by the Senior Economic Advisor to the President and meets on a weekly basis to monitor the progress of the implementation of the I-ANDS and eventually of the ANDS. The Oversight Committee oversees the process of preparing the ANDS.

The Consultative Groups Meetings and the number of Working Groups established under the Compact provided a good stage for dialogue at the national level between Government, donor and civil society on development priorities. On the other hand the Provincial Development Committees (PDCs) and the Governors' Offices played an instrumental role in facilitating the sub-national consultations, making sure that the entire ANDS will be based on a bottom-up rather than a top-down approach. 


\section{Mechanism for Preparation of the ANDS}

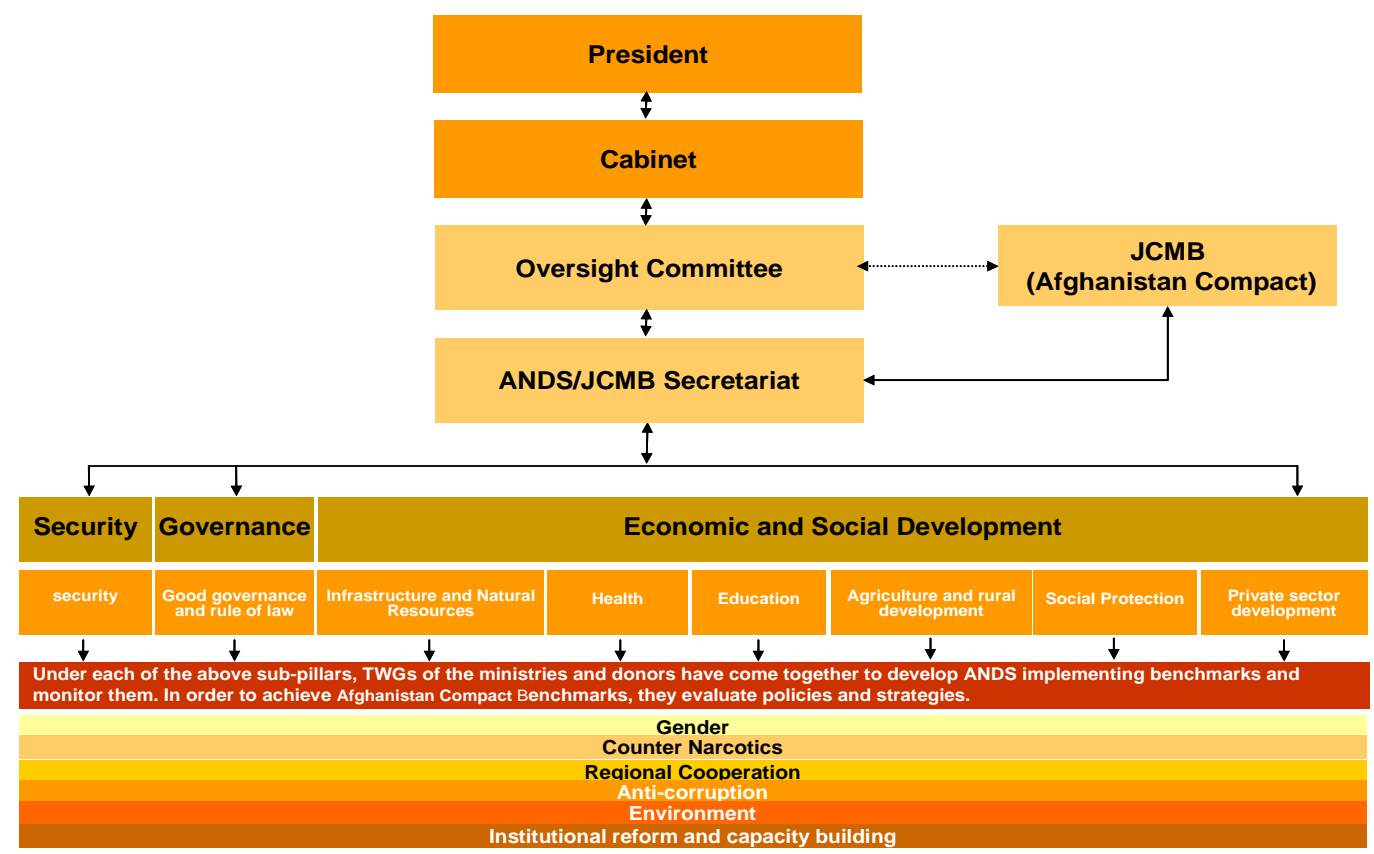

\subsection{Progress to Date}

The sector strategies are emerging from the ANDS process. Ministry strategies have been prepared by the line ministries with the aim of strengthening ministry policies and pave the way for the preparation and implementation of the ANDS sector strategies. Further, the ANDS sector strategies will cover broader issues and policies and will be drafted and prioritized by the group of respective ministries. Finally, the ANDS itself will grow from the ANDS sector strategies with the input from the subnational consultations.

One year after the initiation of the ANDS development phase, progress has been made in all key areas:

- Ministry/Agency strategies have been finalized by the WGs and presented to the Cabinet's Economic Council;

- Sub-national consultations have been completed;

- Consultations with the members of the National Assembly, private sector, civil society, youth, religious leaders, elders, Afghan Diaspora and people in general have taken place;

- Donor dialogue meetings on key development priorities and sector strategies have been organized;

- Ministry/agency strategies and the drafts of the key sector strategies have been presented to the high level Afghanistan Development Forum (ADF) and the JCMB and to other high-level meetings and conferences; 
- 34 Provincial Development Plans (PDPs) and eight city development plans / profiles have been developed;

- Public awareness campaigns have been launched;

- Two poverty surveys (NRVA 2005, NRVA Spring 2007) and analyses were conducted and the First Draft of the ANDS Poverty Profile was prepared;

- The initial ANDS Macroeconomic Framework was drafted;

- Preparation of the ANDS Sector Strategies has reached its final stage;

- The ANDS sector and resource prioritization has been initiated within the OSC and the Cabinet;

- Key sector strategies have been costed and will be integrated into 2008/09 budget;

- The first draft of the ANDS Chapter on Implementation, Monitoring and Evaluation as well as the first draft of Policy Paper on How to Improve Aid Coordination and the Aid-Effectiveness was prepared.

\subsection{Preparation of the Ministry/Agency Strategies}

Forty-three ministry/agency strategies were developed and approved by the ANDS WG after being presented to the Cabinet's Economic Council. The respective ministries and government agencies conducted the drafting. The ANDS Secretariat formulated templates in order to bring uniformity, coordinate and facilitate development of the ministry/agency strategies. The draft strategies were approved by the ANDS Working Groups and presented to the ADF. Despite weak capacity, the respective ministries and agencies demonstrated strong ownership. The sub-national consultations and preparation of the sector strategies have been based on the ministry/agency strategies.

\subsection{Consultative Process}

The ANDS process has placed consultations and participation at the center of its efforts to ensure ownership by the government and the Afghan people. It is the first time in the history of Afghanistan that the Government has conducted broad-based consultations with the people. The overall consultative process was organized at the (a) national (CG Meetings) and the (b) sub-national level (provincial consultations).

The Government, notably the ANDS Secretariat, was responsible for coordinating and facilitating the consultative process. However, the line ministries, especially the Ministry for Rural Rehabilitation and Development (MRRD) and Ministry for Urban Development, have also organized important consultations. At the sub-national level, the PDCs and the Governor's office have played active roles in coordinating the consultations.

The list of stakeholders included: civil society, NGOs, youth associations, private sector representatives, provincial administration, traditional structures (shuras, elders), and members of the National Assembly, donors, PRTs, UN agencies and the Afghan 
diaspora. To date the ANDS consultative process has covered several hundred consultative events.

A nomad woman from Balkh province stated that this was the first time she had attended the meeting on behalf of nomad women of this province in order to present her opinions for the welfare and prosperity of the country. "We would be glad if the government continues to pursue such policy. Nomads like any other people in the society would alsn honefit from this nroress" Farida Korhi renresentative of Ralkh

Whilst the consultations were occurring, the ANDS secretariat launched an intensive public awareness campaign, which aimed to (i) inform the public about the ANDS, (ii) obtain public support for the implementation of the most important ANDS reforms, (iii) manage people's expectations. The public awareness campaign included national and sub national media, paper as well as the electronic media. In the Afghanistan context, the media campaign was an innovative way by the Government to approach the public.

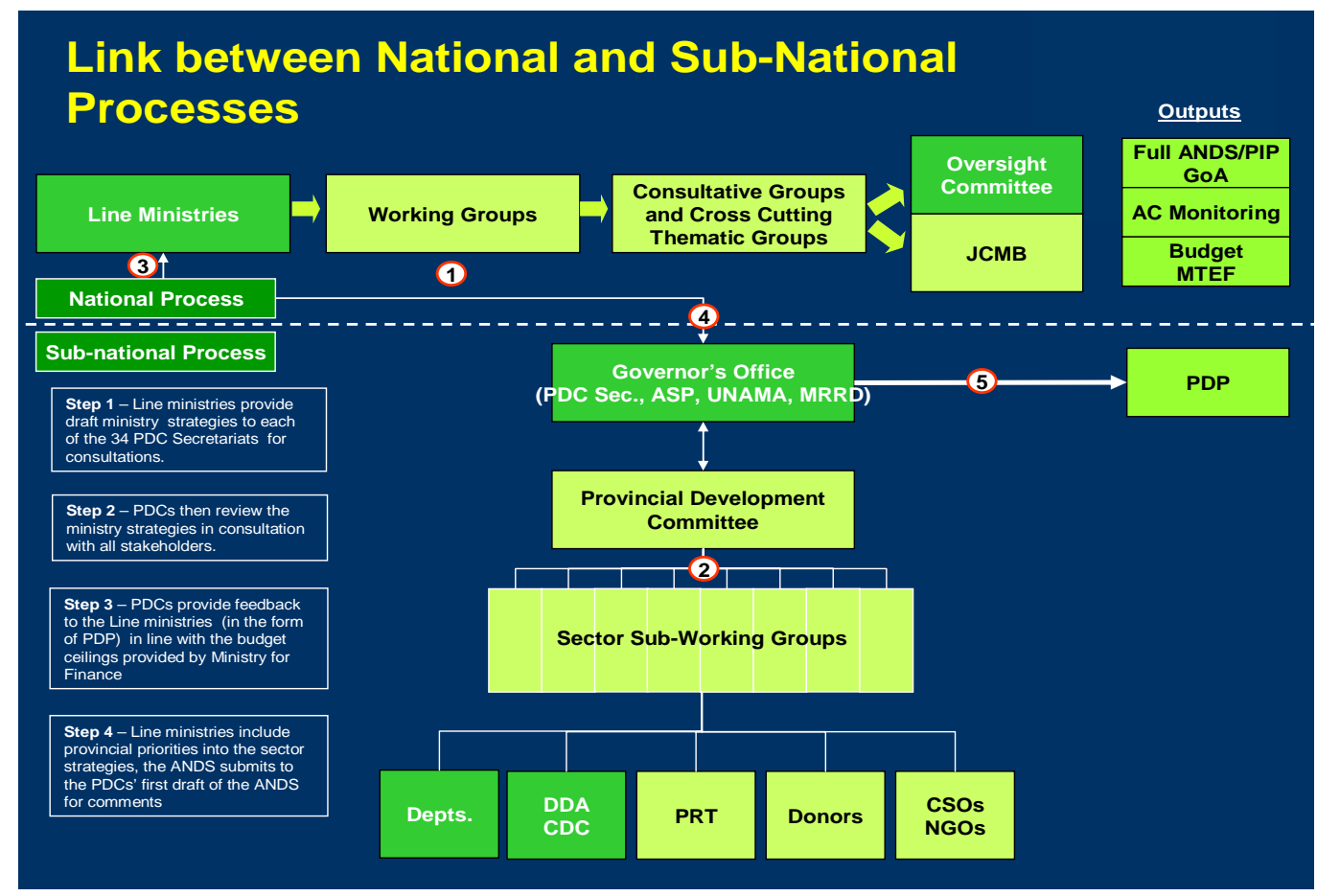

\subsection{Sub-National Consultations}

The sub-national consultations were held in all 34 provinces. They have involved more than 13,000 members of civil society, NGOs, private sector representatives, government administration, religious leaders, elders and donors. Female participation was almost equal to male participation, reflecting the growing role of women in Afghan society. As previously mentioned, the Provincial Development Committees (PDCs) and Governors Offices played crucial role in coordinating the process. MRRD and its National Solidarity and National Area Based Programs were instrumental to the success of the sub-national consultations. This effort was strengthened by the development of the eight regional city profiles/development plans. 


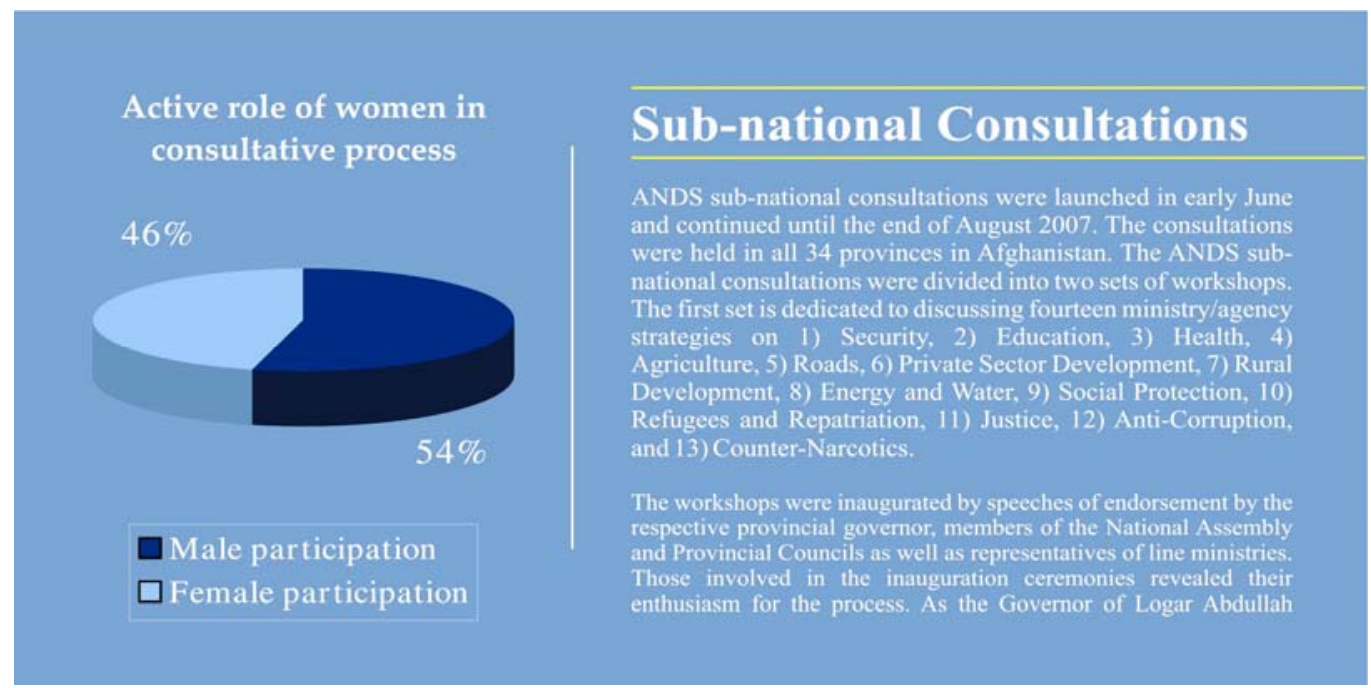

Carrying out sub-national consultations has enabled the ANDS to elicit the knowledge and experience of a wide range of the populace, ranging from members of the $\mathrm{Na}$ tional Assembly to people in the most severely conflict affected areas, and to systematically incorporate their needs and perspectives into the design of the country's national development strategy.

By implementing broad-based and inclusive sub-national consultations, the Government sought to achieve a number of objectives that would last well beyond the timeline for developing the ANDS:

- Through the consultation process, the government began to lay the groundwork for a sustainable process that opens up space for including more of the populace in government decisionmaking and enhancing the accountability of the government to the people.

- The process undertaken for the subnational consultations is also contributing to the creation of a single government led mechanism for integrated development planning in which de-

Narrowing the Gap between the people and the central government

One of the participants in the consultations in Baghlan province commented that "on the first day the distance between the government and the people was 500 meters. Next day the distance narrowed. Last day of consultations the people and the government were speaking the same language." velopment planning at the provincial level is aligned with national development planning, thereby strengthening the links between the central government and the provinces.

- The consultations have also greatly improved the capacity of sub-national administration to take part in national development planning, due to a better understanding of the process. 


\section{Historic opportunity}

"It's the first time in the history of Afghanistan that national strategy is prepared through consultations at provincial level. Thus, it's not only an opportunity, but also a responsibility to have active participation in the preparation and implementation of the Afghanistan $\mathrm{Na-}$ tional Development Strategy.'

Governor from Balkh

\subsection{National Consultative Process: consultations with the private sector, civil society and youth}

Representatives of the private sector, civil society and youth organizations actively participated in the ANDS consultations at the national level through CG meeting and the work of the ANDS WGs. Moreover, important consultative events have also been organized outside of the CG meetings.

"The Enabling Environment Conference" (Kabul, June 2007) that took place within the framework of the Afghan National Development Strategy reaffirmed the important role of the private sector for the future development of Afghanistan. Prior to the conference, a number of consultative events took place in five cities: Kabul, Herat, Kandahar, Mazar-i-Sharif and Jalalabad. The Conference recognized that the fundamental elements of an enabling environment for Afghanistan's vision for development can only be realized when Government, business and civil society work together with a clear understanding of each other's roles and responsibilities, in order to reach a consensus on the ANDS private sector development strategy.

"It has been guided by the Government's commitment to encourage and promote private sector activity, as has been expressed in the Constitution of the Islamic Republic of Afghanistan and the Afghanistan Compact. Outcomes of the Conference could be listed as bellow:

- To develop legal framework for business sector

- To increase access to finance

- To develop economic infrastructure through public-private sector partnership

- To improve access to land

- To Streamline regulations, procedures and improve enforcement

- To address human capacity constrains

- To encourage social responsibility

Concluding Statement, “The Enabling Environment Conference”, Kabul, June 2007

Consultations with civil society and NGOs have taken several forms. Civil society groups and NGOs have been actively involved in the CG meetings and the work of the ANDS WGs. However, two civil society networks (ACBAR and FCCS) have conducted consultations with the extremely poor segments of society and those who might not have an opportunity to participate in planned consultations. These consultations were part of the ANDS consultative processes. They have provided the ANDS Secretariat and line ministries with valuable information about the perceptions of pov- 
erty among the most vulnerable. Several NGOs have conducted consultations in districts affected by the insurgency.

Given that the majority of the Afghan population is below the age of 25 and falls into the Youth category, the consultations with the young population have been regarded as a priority. In most of the cases these consultations have mainly taken place within universities.

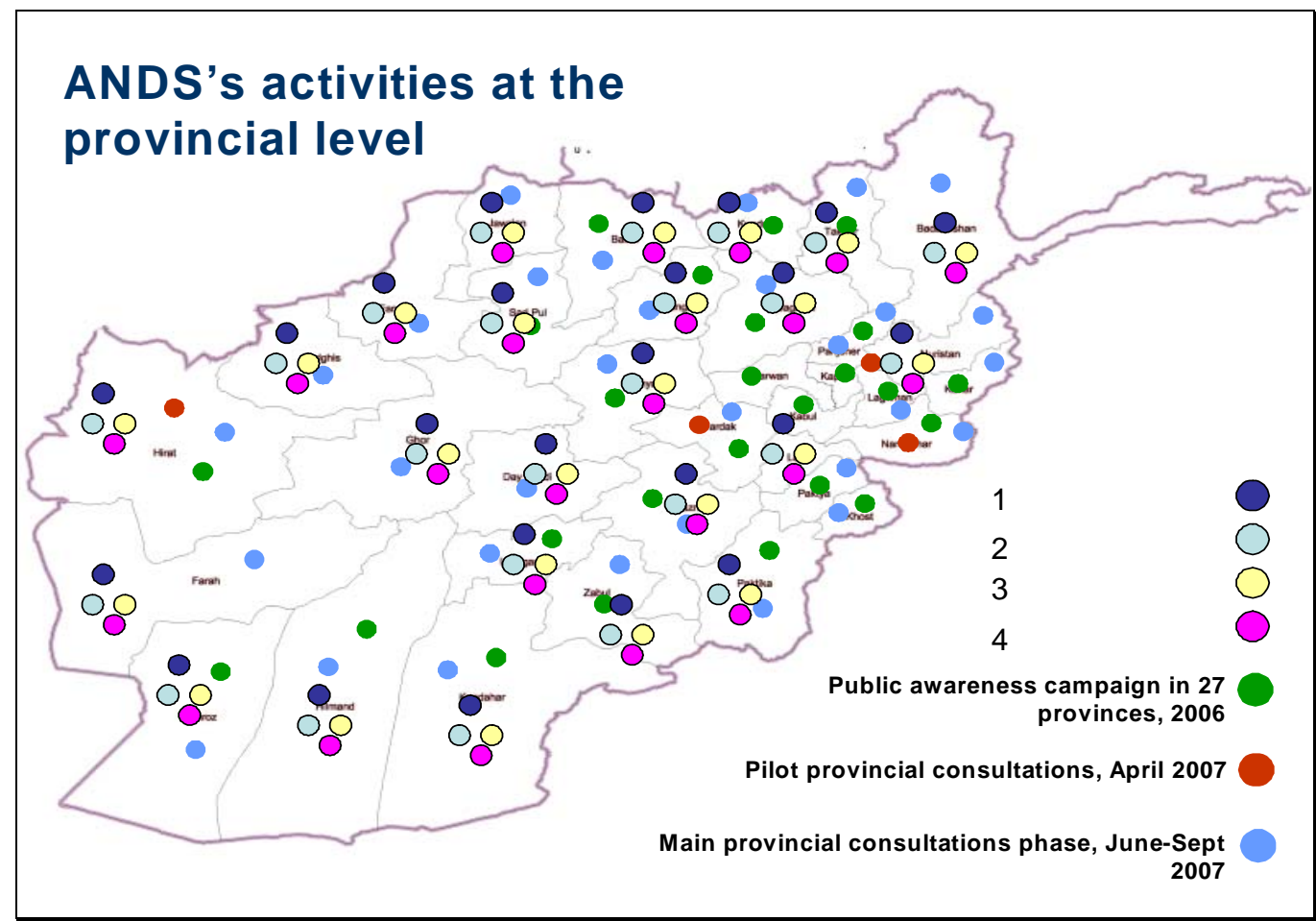

Consultations with the members of the National Assembly and the Provincial Councils were also an important part of the consultative process. Members of the National Assembly have participated in number of the consultative events at the national and the sub-national level.

\subsection{Donor Dialogue}

Consultations with donors have also taken place in several forms. Donors have provided comments on (i) ministry/agency strategies, (ii) sector strategies, and (iii) other parts of the ANDS such as Poverty Profiles, the Macroeconomic Framework, and both the Implementation and Monitoring and Aid Effectiveness chapters. Apart from this, donors have been providing advice about the ANDS process. Finally, through the PDCs the donors have actively participated in the sub-national consultations.

Comments on the ministry/agency strategies have mainly been provided through the CG meetings and through the work of the ANDS WGs. The External Advisory Group (EAG) played an important role and has also been involved in commenting on the ministry/agency strategies and advising the Afghan Government about the ANDS process. However, more importantly the EAG provided the platform for high-level consultations on key development priorities. 
The most important part of the government/donor ANDS dialogue related to the ANDS Sector Strategies. In line with the EAG recommendations, The UN development Programme (UNDP) organized donors into sector working groups with the aim of: (a) conducting donor discussions on the ANDS Sector Strategies; and (b) providing the Government with consolidated donor comments. This government/donor interaction significantly contributed to mainstreaming donor comments into the sector strategies. Other than strong local ownership, a broad-based consultative process and advanced prioritization, the government/donor dialogue represents one of the greatest achievements of the ANDS.

The Afghanistan Development Forum (ADF) was briefed on the development of the ANDS. Moreover, all ministry/agency strategies were presented to the ADF in April 2007 while the ANDS developments, ministry and sector strategies were presented to the high-level JCMB meetings every three months.

\section{Preparation of the PDPs}

The outcome of the ANDS sub-national consultations was the finalization of the 34 provincial development plans (PDPs). These had been initiated in previous years and were intended to serve as a document for setting out the strategic goals for development in each province. The PDPs had been produced with varying levels of success and therefore the opportunity existed for ANDS to help standardise and improve on the pilots.

The new PDPs have been developed in line with the sectors of the ANDS; providing a framework for development actors within national objectives and as a direct response to provincial needs.

The main objectives of the

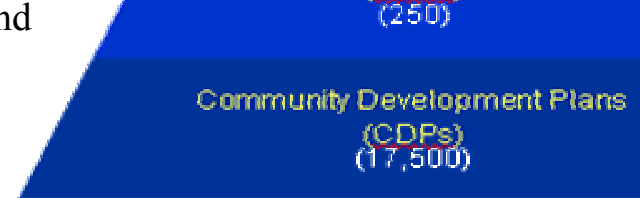

ANDS for the new PDP process were to: (i) ensure broad public based support for and input into the ANDS, (ii) abolish all parallel mechanisms for development planning at the national and sub national level, (iii) enhance national and sub-national capacity in development planning, and (iv) ensure effective integration of the provincial needs into the national budget, leading to more equitable development spending and better public service delivery, and (v) manage the expectations of the people.

Preparation and prioritisation of the PDPs has significantly contributed to managing the expectations of the people of Afghanistan. The few PDPs that had previously been prepared have been criticized as being too donor driven and resembling "wish lists". Strong participation of the line ministries, the proactive role of the provincial governors, The representation of a cross section of Afghan society, including $47 \%$ women, has led to the preparation of realistic development plans, with an emphasis on increasing the effectiveness and clarity of the sub national governance institutions. 
The sub-national consultations and the PDP process were built on the MRRD's efforts to develop the Community and District Development Plans. In the last three years, through the National Solidarity and the National Area Based Programs, the MRRD helped to establish more than 17,500 Community Development Plans (CDPs) and around 250 District Development Plans (DDPs). Moreover, the Ministry for Urban Development facilitated preparation of the eight city development plans. As part of ongoing communications and reporting on the SNC process, participants at a recent 4day CDC Community District Council Conference in Kabul were updated on ANDS sector and PDP prioritisation and implementation. The Conference was attended by more than $500 \mathrm{CDC}$ representatives from across Afghanistan.

All these sub-national development plans together with the inputs from the consultative events have served as a basis for preparation of the PDPs and for deepening the Afghan ownership of the ANDS process. Given this, the integration of the PDPs into the ANDS is one of the highest priorities for the finalization of the ANDS.

\section{Poverty Analysis}

The ANDS is Afghanistan's Poverty Reduction Strategy Paper (PRSP). Its policies will have to be based on evidence. Thus, research was a vital part of the overall development of the ANDS. To improve poverty data, the Central Statistics Office (CSO) together with the MRRD and in coordination with the ANDS, launched two national risk and vulnerability surveys (NRVA 2003 and 2005). Around 45,000 households from all over the country were interviewed. This led to preparation of a comprehensive poverty analysis in 2007, which has been used as a basis for drafting the ANDS Poverty Profile and for formulation of the ANDS poverty reduction policies.

\section{Poverty rate in Afghanistan}

\begin{tabular}{|c|c|c|c|}
\hline & Food poverty & CBN poverty & Food insecurity index \\
\hline Spring 2007 & & & 39 \\
\hline Kuchi & 40 & 45 & 39 \\
\hline Rural & 45 & 45 & 37 \\
\hline Urban & 41 & 27 & 39 \\
\hline
\end{tabular}

The First Draft of the ANDS Poverty Profile 


\section{Finalization of the ANDS Sector Strategies}

The development of the fully costed, prioritized and sequenced Sector Strategies (ANDS SS) has always been important priority for the ANDS process. In order to ensure full ownership, the Government established nineteen Sector Strategy Development Groups (SSDGs). All of them led by the respective line ministries. By midOctober 2007 all nineteen first drafts of the ANDS Sector Strategies were prepared and approved by the SSDGs. They have been shared with donors, civil society, youth organizations and other stakeholders. Through the UNDP-established donor dialogue process, donors have already provided comments for most of the sector strategies, while comments from other stakeholders are due by end-November 2007.

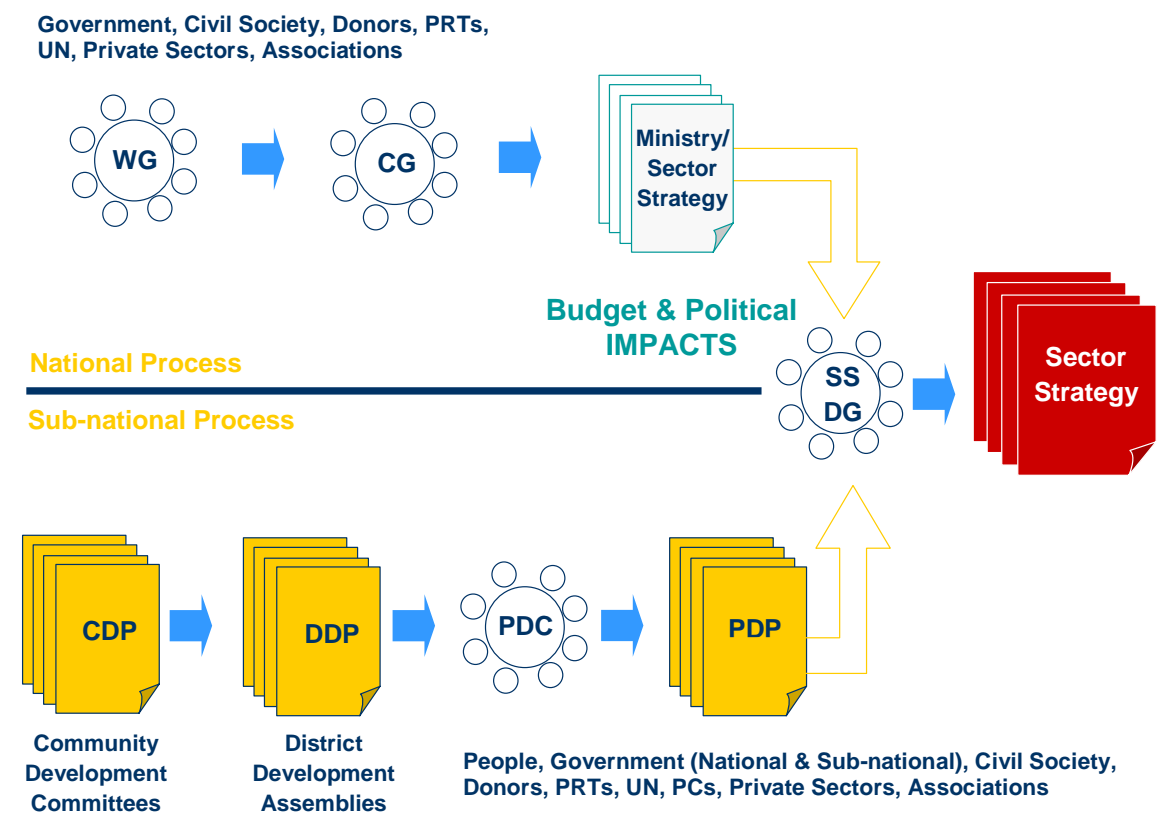

\section{Prioritization and Budget Integration}

The Government of Afghanistan intends to develop the ANDS as a document, which will be realistic for implementation. With respect to this, the Ministry of Finance (MoF) together with the DAB (Central Bank of Afghanistan), CSO (Central Statistics Office) and the ANDS Secretariat has developed a First Draft of the ANDS Macroeconomic Framework with the aim to (i) identify the sources of growth and (ii) overall resource envelop for financing the ANDS.

Based on the Macroeconomic Framework, the ANDS Oversight Committee (OSC) initiated a number of high-level meetings to prioritize future spending across and within the sectors. The MoF and the ANDS Secretariat have developed the prioritization criteria that have ranged from identification of the medium-term budget ceilings to the capacity of the line ministers to implement projects. 
The discussion on prioritization was held at a high-level (OSC) and at the same time it was Afghan-owned, although key donors were also consulted. For the first time in recent history, members of the Afghan Government clearly articulated future development priorities despite the fact that it required that tough choices be made. In order to reduce poverty, key sectors for poverty reduction, such as Education, Health and Transport and Energy, have been given the highest priority for the implementation of the ANDS.

Prioritization has significantly improved the quality of the ANDS process. It has been supported by the activities of the MoF and the line ministries to cost key sector strategies. The MoF has drafted initial costing methodology and coordinated the overall work of the line ministries to cost, prioritize and sequence sector strategies. This effort was supported by the already developed capacities of the MoF for program budgeting in all key ministries.

The Government of Afghanistan has decided to use its budget as a key instrument for development. Thus, integration of the ANDS Sector Strategies into the Core Budget is regarded as the top priority. Three key sector strategies for poverty reduction (Education, Health and Transport) will be integrated in 2008/09 budget, while the rest of the sector strategies will be integrated into the 2009/10 budget.

The MoF has conducted the Donor Financial Review, which proved that donor coordination and aid effectiveness was weak. This has strengthened the case for greater involvement of donors in the ANDS process and a stronger alignment and adjustment of their future programs and projects within ANDS priorities.

\subsection{Aid Coordination and Aid Effectiveness}

Implementation of the ANDS will be highly dependent on donor assistance. Thus, the ANDS process included discussions on how to improve aid coordination and aid effectiveness. The first draft of the ANDS chapter on Aid Coordination has been drafted and will be shared with donors from the end of November.

\subsection{Implementation, Monitoring and Evaluation}

That ANDS / JCMB Secretariat plays a key role in the monitoring and implementation of the Compact benchmarks. Thus, supporting the Government's overall effort in improving the capacity to monitor development policies has always been an important focus of the ANDS Secretariat.

The ANDS Secretariat will also be responsible for monitoring the ANDS and Compact benchmarks. Thus, it has already embarked on the process of identification of suitable monitoring indicators. The current Centralized Monitoring and Reporting System (CMRS) is being developed as the data collection, management, reporting and information dissemination system on the Afghanistan development process. The CMRS will support the JCMB in its monitoring role through the data capturing mechanisms but it requires further assistance. Moreover, the Monitoring Matrix (MM) of around 400 indicators has already been developed. The First Draft of the ANDS chapter on Implementation, Monitoring and Evaluation has been drafted and will be shared with other stakeholders by mid-December 2007. 


\section{Next Steps and Challenges}

\subsection{Institutionalization of the ANDS}

The ANDS has been institutionalized within the Afghan Government and sub-national administrations. However, further steps will be taken to strengthen the ANDS' role in implementation and monitoring. Apart from coordinating the work in finalizing the ANDS, the ANDS Secretariat and the MoF will focus future activities on coordinating the Government's efforts to align programs and projects with the ANDS Sector Strategies and to develop the National Public Investment Program (PIP). Moreover, efforts will be made to broaden poverty analysis. Particular attention will be paid to the preparation of the Government for the Donor Pledging Conference, which should address the overall ANDS funding gap, and the preparation of the ANDS / PRSP March 2009 Progress Report, which will form the basis for the HIPC conference.

\subsection{Next Steps}

The ANDS (PRSP) preparation will be finalized with the Cabinet's approval by endMarch 2008 after which the ANDS will be submitted to the Board of Directors of the World Bank and the IMF. The priority for the next period will be to:

- Finalize the preparation of the ANDS Sector Strategies:

- Integrate the PDPs

- Integrate donor comments as well as comments from civil society, NGOs and youth associations

- Integrate cross cutting issues including poverty

- Costing, prioritization and sequencing

- Improve program and project preparations

- Complete cross sector and sector prioritization

- Integrate Education, Health and Transportation sector strategies into the 2008/09 budget

- Finalize the ANDS Poverty Profile

- Finalize the ANDS chapter on Implementation \& Monitoring and Evaluation

- Finalize ANDS chapter on Aid Coordination and Aid Effectiveness

- Improve the ANDS'conflict analysis

- Prepare the First Draft of the ANDS

- Complete the consultations on the First Draft of the ANDS within CG and ANDS WG meetings

- Complete the consultations on the First Draft of the ANDS with subnational administrations (Governors)

- Finalize the ANDS by integrating the

\section{Costing and Prioritization}

Ministry of Finance (MoF) is coordinating

the process of costing of the sector strate-

gies. The ANDS Oversight Committee of

most prominent ministers (including MoF)

has conducted cross sector prioritization in

line with the medium-term budget ceil-

ings, which will need to be approved by

the Cabinet. Based on the Cabinet's deci-

sion the MoF will integrate sector strate-

gies into the Budget. 
national and sub-national comments

- Present the ANDS (PRSP) to the Cabinet

- Submit the ANDS (PRSP) to the Board of Directors of the World Bank and the IMF

It is important to stress that costing and integration of the ANDS into the budget will continue after March 2008. In this respect, the ANDS / JCMB Secretariat will:

- Coordinate the process of formulating new program/projects and adjusting the existing program/projects to support the implementation of the ANDS Sector Strategies. This task will be implemented in close coordination with the MoF and its current efforts to develop the program budget;

- coordinate the process of preparing the National Public Investment Program (PIP);

- Coordinate the Government's activities for preparing the Donor Pledging Conference in order to address the overall ANDS funding gap;

- Support the efforts of the CSO to develop indicators for monitoring ANDS policies;

- Prepare the poverty analysis based on the NRVA reports and update the ANDS in light of these reports;

- Monitor the implementation of the ANDS in 2008/09 and prepare the First ANDS Implementation Progress Report by March 2009 (which is the basis for the PRGF and the HIPC).

The Ministry of Finance will:

- Continue to coordinate costing and prioritization of the remaining ANDS Sector Strategies;

- Integrate all the ANDS Sector Strategies into 2009/10 budget;

- Submit to the Board of Directors of the World Bank and the IMF the First ANDS Implementation Progress Report (March 2008-March 2009) to enable Afghanistan to reach a completion point for debt relief under the IMFdesigned Heavily Indebted Poor Countries' facility (HIPC).

\section{ANDS Timeline}

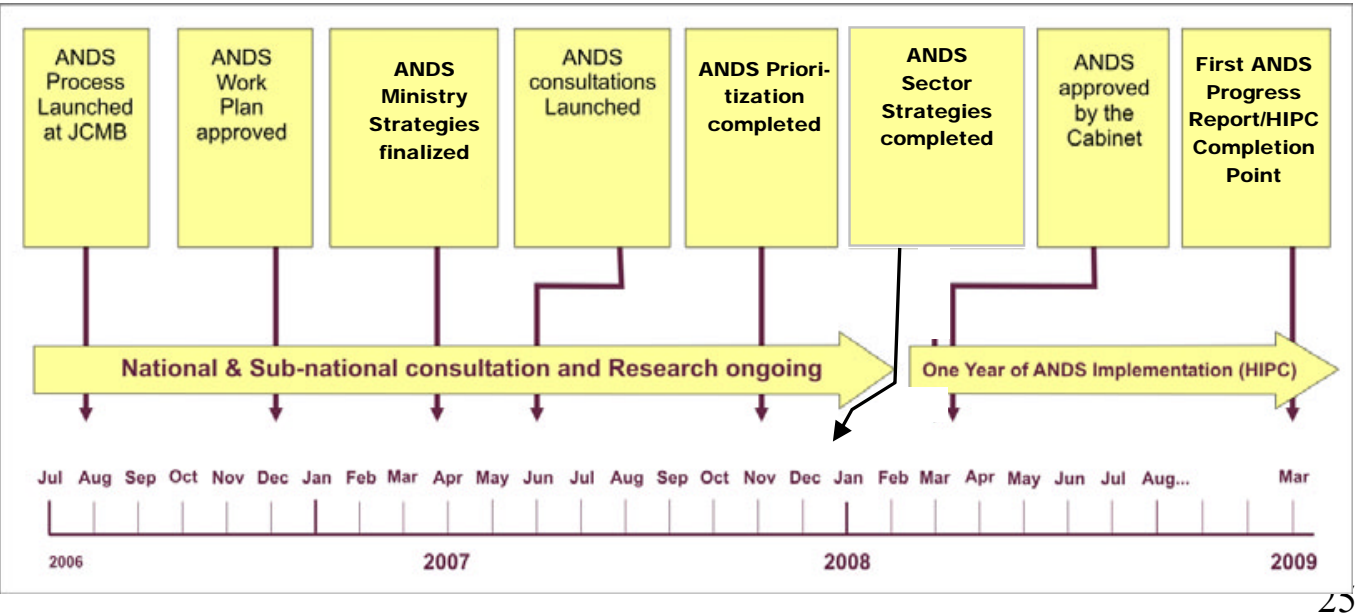




\section{Challenges and Risks}

The ANDS preparation has reached a critical period. The finalization of the prioritized sector strategies, which would include integration of the PDPs and the cross cutting issues will remain the most important challenge and risk for this year.

However, the challenges for next year are even bigger, particularly those related to developing inter-sector linkages and finalization of the ANDS/PRSP by end-March 2008. The biggest risks for finalization of the ANDS are related to (i) completion of the cross-sector prioritization and to (ii) reaching a consensus over the ANDS/PRSP within the Cabinet. Successful implementation of the ANDS in 2008/09 will also be an important challenge given its relation with the debt relief (HIPC) and the PRGF completion.

The Government of Afghanistan will continue to support the ANDS process. However, the implementation of the ANDS will be highly dependant on donor assistance. The ANDS baseline macroeconomic scenario will be consistent with the mediumterm fiscal framework and with the PRGF program with the IMF. Nevertheless, implementation of the ANDS programs and projects will require more resources and without additional donor support, it will not be possible to implement them. Thus, in conjunction with the finalization of the ANDS, the Government and donor collaboration in preparing the next Donor Pledging Conference will be indispensable to ensuring that the funding gap for the implementation of the ANDS programs and projects are covered. 